areas are recognized, but those south of Shropshire do not count for much. Broadly speaking, the workable deposits are concentrated in the Shelve district of Salop, Derbyshire, Yorkshire, Cumberland, Durham, and Northumberland. Nearly all the northern ones are in Carboniferous rocks, even a few in the Coal Measures, but in Shropshire in the Ordovician, with some in the Western Longmyndian.

\title{
CORRESPONDENCE
}

\section{THE OCCURRENCE OF MOINE SCHISTS IN IRELAND}

SIR,-In Counties Donegal (Eire) and Fermanagh (Northern Ireland), near Ballyshannon, Belleek, and Pettigo, there is an extensive tract of hill and moorland country, north of the River Erne and Lough Erne, occupied by metamorphic rocks. On Sheets 24, 31, and 32 of the one inch to the mile Geological Map of Ireland, these metamorphic rocks are depicted in a different colour from metamorphic rocks further north forming the greater part of County Donegal. In the Explanatory Memoir on Sheets 31 and 32 (1891), it is suggested that while these more northerly metamorphic rocks can be correlated with the Dalradian Schists of Scotland (a view now generally accepted), the metamorphic rocks near Lough Erne belong to an older formation of Lewisian (Archean) age. A description of the schists near Pettigo was later given by Cole (1900), ${ }^{1}$ who also believed them to be of Archean age.

Recently the writer had the opportunity of examining the metamorphic rocks near Ballyshannon and Lough Erne. In his opinion there is no resemblance between these rocks and the Lewisian Gneisses of Scotland. On the other hand, the appearance in the field and the lithology of these rocks are such that the writer has no hesitation in correlating them with the Moine Schists of Scotland, a view which is supported by comparison of hand specimens and thin sections with those of Moine Schists from various parts of the Scottish Highlands.

The commonest rocks are well bedded quartz-mica-granulites or psammitic schists varying from white, highly quartzose types to darker, grey, biotite-rich types. Thin, muscovite-rich laminae are usually present ; minor bedding planes are marked by thin colour layers, due to the concentration of dark minerals. Current-bedding was noted at several localities. Thoroughly pelitic rocks (muscovite-biotite-schists) are also present. Small intrusions of epidiorite (hornblende-schist) are common. In the western part of the area, near Ballyshannon, the rocks are of fairly low metamorphic grade and are strikingly straight-bedded and flaggy in appearance. Further east they become more coarsely crystalline, are often massive, and the bedding is locally strongly contorted. In this area of higher metamorphism pegmatite veins are abundant, while the pelitic schists are intimately injected with pegmatitic material along the foliation planes.

North of Lough Derg the metamorphic rocks for which a Moine age is here postulated pass under the Dalradian rocks (quartzites, mica-schists, and limestones). On their west and south-west sides they are unconformably overlain by Carboniferous strata, and to the east

${ }_{1}$ On Metamorphic Rocks in Eastern Tyrone and Southern Donegal. Trans. Roy. Irish Acad., vol. xxxi, pp. 431-471. 
and south-east they are brought against similar strata by a powerful north-easterly fault.

In Scotland the Moine Schists have long been known to occupy vast areas, both in the Northern Highlands, and in the Central Highlands where they pass southwards under the Dalradian. Their reappearance on the south-west side of the latter in Ireland not only greatly extends the known range of the Moine Schists, but also suggests that they form a basement for much, if not all, of the younger Dalradian formation.

On completion of further field and petrographic work it is hoped to publish a more detailed account.
19 Grange Terrace,
Edinburgh.
17 th July, 1946.
J. G. C. Anderson.

\section{CAEN UNIVERSITY GEOLOGY DEPARTMENT}

SIR,--In Volume 81, No. 5 (Sept.-Oct., 1944) you were good enough to publish our appeal on behalf of the Geology Department of Caen University. We would like to thank the numerous donors who responded beyond our hopes, and we think it would interest them individually to know what they have collectively enabled us to do to help Caen in its plight.

Donations amounted to $£ 1467 s$., of which we have spent $£ 645 s$. $6 \mathrm{~d}$. on British geological books and maps, and some $£ 20$ on a prism binocular, pocket lenses, and Canada balsam, all asked for by Professor Dangeard. The most valuable single donation in kind was a set of the Quarterly Journal from vol. 23 (1867) to the present day, presented by Mr. A. G. Stenhouse, together with numerous Survey memoirs and Summaries of Progress, and a dozen standard geological books now for the most part unobtainable. Bristol University are sending independently 13 more volumes of the Quarterly Journal, taking the set back to volume 10 (1854), a nearly complete set of the Palaeontographical Society's monographs and a nearly complete run of the Geological Magazine from Vol. 1 to, Vol. 67 (1930). We have completed the Geological Magazine as far as it is in print, at a cost of $£ 2318 \mathrm{~s}$. $6 d$., and the Council of the Palaeontographical Society has presented the parts needed to complete the set of their monographs. We have also been promised a run of the Proceedings of the Geologists' Association from 1920 to 1944. In addition, we have received and forwarded about $40 \mathrm{lb}$. of reprints and, through the War Office, a set of 85 maps of France on the 1/80,000 scale; and other donors have sent representative collections of labelled British Cretaceous and Tertiary fossils. It is proposed to hold the remainder of our funds in reserve for the purchase of other books asked for by Professor Dangeard, but not at present obtainable, and important Geological Survey publications as they become available.

We are indebted to the British Council for forwarding the books and collections piecemeal. Everything sent has been reported by Professor Dangeard as arrived in good condition.

10 th May, 1946.

J. A. Douglas,
W. B. R. KING,
C. J. STUBbLEFIELd,
C. W. Wright,
W. J. ARKELL.

